Int. J. Dev. Biol. 52: 963-967 (2008)

doi: $10.1387 / \mathrm{ijdb} .072404 \mathrm{wh}$

\title{
The embryonic cell lineage of the nematode Rhabditophanes sp.
}

\author{
WOUTER HOUTHOOFD, MAXIME WILLEMS, KIM JACOBSEN, AUGUST COOMANS and GAETAN BORGONIE* \\ Department of Biology, Ghent University, Ghent, Belgium
}

\begin{abstract}
One of the unique features of the model organism Caenorhabditis elegans is its invariant development, where a stereotyped cell lineage generates a fixed number of cells with a fixed cell type. It remains unclear how embryonic development evolved within the nematodes to give rise to the complex, invariant cell lineage of $C$. elegans. Therefore, we determined the embryonic cell lineage of the nematode, Rhabditophanes sp. (family Alloionematidae) and made detailed cell-by-cell comparison with the known cell lineages of $C$. elegans, Pellioditis marina and Halicephalobus gingivalis. This gave us a unique data set of four embryonic cell lineages, which allowed a detailed comparison between these cell lineages at the level of each individual cell. This lineage comparison revealed a similar complex polyclonal fate distribution in all four nematode species $(85 \%$ of the cells have the same fate). It is striking that there is a conservation of a ' $C$. elegans' like polyclonal cell lineage with strong left-right asymmetry. We propose that an early symmetry-breaking event in nematodes of clade IV-V is a major developmental constraint which shapes their asymmetric cell lineage.
\end{abstract}

KEY WORDS: 4D microscopy, cell lineage, embryo, evolution, nematode, Rhabditophanes sp

The model organism Caenorhabditis eleganshas a strict invariant cell lineage, generating a predetermined number of cells each with a fixed cell type (Sulston and Horvitz, 1977; Sulston et al., 1983). The reproducibility of this lineage has allowed scientists to study developmental mechanisms on a cellular level, greatly improving knowledge in many fields of biology and medicine (Wood, 1988; Riddle et al., 1997; The C. elegans Research Community, 2005). Recent research on other nematode species throughout the phylum has uncovered much more diversity in developmental mechanisms than was previously thought. But most of this research focuses on specific phases or areas of development, like the early development (reviewed in Schierenberg, 2006) or development of the gonad, vulva and male tail (reviewed in Sommer, 2005). So, it remains unclear whether these different mechanisms are part of a different mode of development or fit into the invariant « $C$. elegans like» mode of development. The study of the embryogenesis of more nematodes will teach us about the different strategies to form a nematode body plan and how these strategies are evolutionarily linked to one another.

The description of the embryonic cell lineage of Pellioditis marina demonstrated that this cell lineage is conserved within the family Rhabditidae (clade V) according to the phylogeny of
Blaxter et al. (1998) (Houthoofd et al., 2003). To examine the extent of conservation of this mode of development in nematodes, we established the embryonic cell lineages of more distantly related nematodes from the adjacent clade IV. Recently, we determined the embryonic cell lineage of Halicephalobus gingivalis (Houthoofd and Borgonie, 2007). Here we present the nearly complete embryonic cell lineage of the free-living nematode Rhabditophanessp. KR 3021 (fam. Alloionematidae). This gives us a unique data set of four embryonic cell lineages, which allows a detailed comparison between these cell lineages on the level of each individual cell.

The embryonic development of Rhabditophanessp. is comparable to that of $C$. elegans, $P$. marina and $H$. gingivalis, with differences in the early division sequence and gastrulation. The division of $A B$ and $P_{1}$ occurs simultaneously and results in a short transient $\mathrm{T}$-shape that immediately converts to the rhomboid configuration (Fig. 1A,B). Gastrulation starts at the 32-cell stage, with the stepwise ingression of the four granddaughters of the intestinal precursors $\mathrm{E}$ (Eal, Ear, Epl, Epr), which lie in a square at the ventral side of the embryo (Fig. 1C). This is in contrast with the other species compared here, where gastrulation starts with the ingression of the two daughters of E, Ea and Ep.

At muscle contraction, the consensus lineage of

\footnotetext{
Published online: 14 August 2008

0214-6282/2008/\$35.00

(c) UBC Press

Printed in Spain

www.intjdevbiol.com
}

*Address correspondence to: Gaëtan Borgonie. Department of Biology, Ghent University, K.L. Ledeganckstraat 35, B-9000 Ghent, Belgium.

Fax: +32 926453 44. e-mail: gaetan.borgonie@ugent.be 

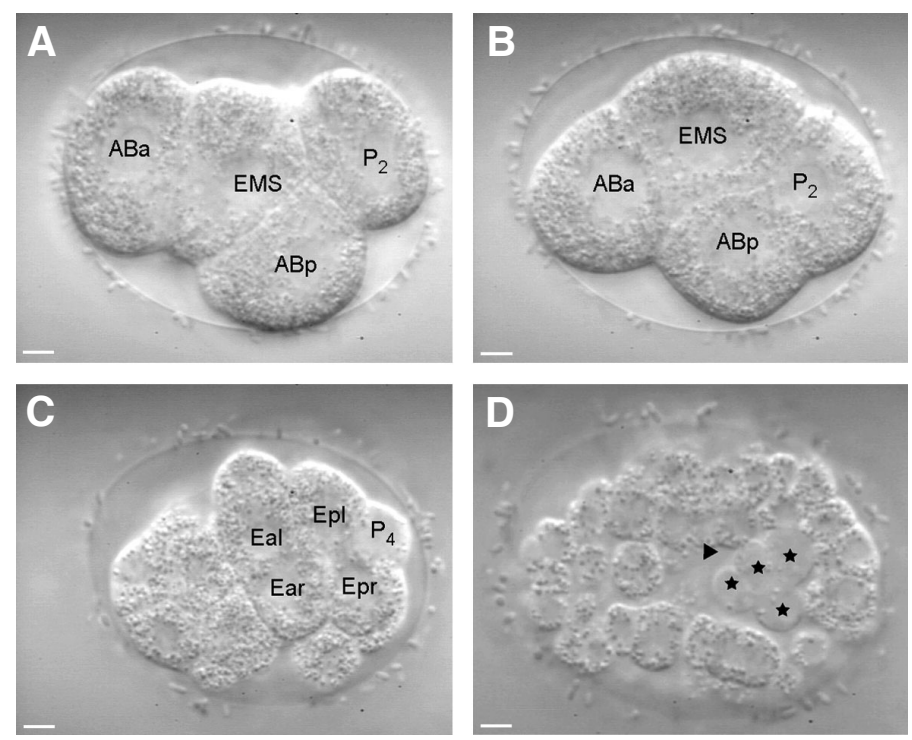

Fig. 1. DIC images of different embryonic stages in Rhabditophanes sp. (A) Early T-shaped 4-cell stage, left lateral view, just after division of $A B$ and P1. (B) Late rhomboid shaped four cell stage, left lateral view. EMS lies at the future ventral side of the embryo, ABp at the future dorsal side. (C) 32-cell stage, ventral view. The four E cells lie at the ventral side just before gastrulation. (D) Ventral view of 176 cell stage $(176 \mathrm{~min})$, anterior to the left. The four primordial germ cells are marked with an asterisk. Arrowhead indicates the blastocoel, the space left after the inward migration of the intestinal cells. All stages anterior to the left, scalebar is $5 \mu \mathrm{m}$.

Rhabditophanes sp. contains 606 terminal cells (Table 1). The position and fate of 552 of these $(91 \%)$ was determined (the position and fate of 36 cells and the division of 18 cells could not be resolved). The cellular composition of the embryonic tissues differs in some aspects with the other species. The intestinal cell lineage $\mathrm{E}$ forms 20 cells in a similar pattern as in C. elegans and $P$. marina, but it is the last but one pair of cells in the $16 \mathrm{E}$ stage, $\mathrm{Ep}(1 / \mathrm{r}) \mathrm{a}$, that divides to form a 7 th and 8th ring, while in $P$. marina and $C$. elegans, these rings are formed by a division of the last pair of cells (Houthoofd et al., 2006). The primordial gonad consists of four germ line cells, due to an extra division round of $\mathrm{P}_{4}$ (Fig 1D). Only 21 programmed cell deaths could be identified in the Rhabditophanes sp. embryo (Table 1). All these cells have an equivalent cell death in C. elegans and 15 of those cells are early cell deaths after the ninth division round. Of the 70 cells that undergo cell death in C. elegans, but not in Rhabditophanessp., the fate and position of 47 could be determined (neurons (35), pharynx (10), epidermis (2)). Of the remaining 23 cells, the position and fate could not be ascertained from the Rhabditophanes $\mathrm{sp}$. recordings. It is however possible that these cells also undergo cell death, but this could not be confirmed in the recordings.

\section{Cells are built according to similar cell lineages}

A first striking conclusion after a cell-by-cell comparison between the four species is that cells are built according to a very similar cell lineage in the four species (Fig. 2). The lineage similarity between Rhabditophanessp. and C. elegans is $93.6 \%$, indicating that 517 of the 552 determined terminal cells have an equivalent terminal cell with the same lineage history in the $C$. elegans cell lineage. Next, we compared the fate of each equivalent cell (with an identical lineage history) between the four cell lineages (Fig. 2). For example, 454 of the 517 terminal cells in Rhabditophanes sp. have the same fate as in C. elegans. That makes a fate similarity of $88 \%$ (Fig. 2). This fate similarity is unequally distributed over the different tissues. Intestine (80$100 \%)$, body muscle (94-100\%) and epidermis (88-95\%) in Rhabditophanes sp. have a high fate similarity compared to the other species. Pharynx (70-87\%) and nervous system (67-79\%) have a lower similarity (similar percentages for other species, data not shown).

A comparison of the fate distribution of the $A B$ lineage of Rhabditophanessp. with the other species shows that despite the interspecific variation, there are some important similar fate distribution patterns, which might shed light on possible underlying mechanisms. The fate distribution of $A B$ in $C$. elegans is regulated by a series of four Notch mediated inductions, which results in a specific fate distribution for each of the $8 \mathrm{AB}$ greatgranddaughters (reviewed in Priess, 2005) (Fig. 3). Firstly, an induction from the germline precursor $P_{2}$ to $A B p$ results in a

TABLE 1

COMPARISON OF THE NUMBER OF CELLS PER TISSUE TYPE (ROW) AND FOUNDER CELL (COLUMN)

\begin{tabular}{|c|c|c|c|c|c|c|c|c|c|c|c|c|c|c|c|c|c|c|c|c|c|c|c|c|c|c|c|c|}
\hline & \multicolumn{4}{|c|}{$A B$} & \multicolumn{4}{|c|}{ MS } & \multicolumn{4}{|c|}{ E } & \multicolumn{4}{|c|}{ C } & \multicolumn{4}{|c|}{ D } & \multicolumn{4}{|c|}{ P4 } & \multicolumn{4}{|c|}{ total } \\
\hline & Rh & $\mathrm{Hg}$ & $\mathrm{Pm}$ & $\mathrm{Ce}$ & $\overline{R h}$ & $\mathrm{Hg}$ & $\mathrm{Pm}$ & $\overline{\mathrm{Ce}}$ & $\overline{R h}$ & $\mathrm{Hg}$ & $\mathrm{Pm}$ & $\overline{\mathrm{Ce}}$ & $\overline{R h}$ & $\mathrm{Hg}$ & $\mathrm{Pm}$ & $\overline{\mathrm{Ce}}$ & $\overline{R h}$ & $\mathrm{Hg}$ & $\mathrm{Pm}$ & $\mathrm{Ce}$ & $\overline{R h}$ & $\mathrm{Hg}$ & $\mathrm{Pm}$ & $\overline{\mathrm{Ce}}$ & $\overline{R h}$ & $\mathrm{Hg}$ & $\mathrm{Pm}$ & $\mathrm{Ce}$ \\
\hline Pharynx & 63 & 60 & 79 & 56 & 32 & 31 & 33 & 30 & & & & & & & & & & & & & & & & & 95 & 91 & 112 & 86 \\
\hline Neuron & 214 & 199 & 186 & 211 & 2 & 1 & 7 & 6 & & & & & 2 & & 2 & 2 & & & & & & & & & 218 & 200 & 195 & 219 \\
\hline Muscle & 1 & 1 & 1 & 1 & 29 & 33 & 28 & 28 & & & & & 32 & 32 & 32 & 32 & 20 & 20 & 20 & 20 & & & & & 82 & 86 & 81 & 81 \\
\hline Epidermis & 72 & 74 & 114 & 66 & & & 3 & & & & & & 14 & 16 & 14 & 13 & & & & & & & & & 86 & 90 & 131 & 79 \\
\hline Intestine & & & & & & & & & 20 & 18 & 20 & 20 & & & & & & & & & & & & & 20 & 18 & 20 & 20 \\
\hline Other & 16 & 18 & 20 & 20 & 10 & 7 & 10 & 11 & & & & & & & & & & & & & & & & & 26 & 25 & 30 & 31 \\
\hline Gonad & & & & & & & & & & & & & & & & & & & & & 4 & 2 & 2 & 2 & 4 & 2 & 2 & 2 \\
\hline Mitosis & & & & 26 & & & & 3 & & & & & & & & & & & & & & & & & & & & 29 \\
\hline Total survivors & 366 & 352 & 400 & 380 & 73 & 72 & 81 & 78 & 20 & 18 & 20 & 20 & 48 & 48 & 48 & 47 & 20 & 20 & 20 & 20 & 4 & 2 & 2 & 2 & 531 & 512 & 571 & 547 \\
\hline Cell death & 12 & 18 & 58 & 78 & 9 & 4 & 9 & 13 & & 2 & & & & & & & & & & & & & & & 21 & 24 & 67 & 91 \\
\hline Unresolved mitosis & 15 & 13 & & & 3 & & & & & & & & & & & & & & & & & & & & 18 & 13 & & \\
\hline Unresolved cell & 33 & 38 & & & 3 & 10 & & & & & & & & & & & & & & & & & & & 36 & 48 & & \\
\hline Total cells produced & 426 & 421 & 458 & 458 & 88 & 86 & 90 & 91 & 20 & 20 & 20 & 20 & 48 & 48 & 48 & 47 & 20 & 20 & 20 & 20 & 4 & 2 & 2 & 2 & 606 & 597 & 638 & 638 \\
\hline
\end{tabular}

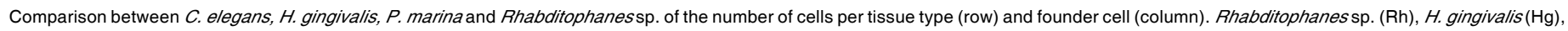


reversed distribution of the epidermal precursors arising from $\mathrm{ABa}$ (mainly in posterior granddaughters $\mathrm{ABa}(\mathrm{l} / \mathrm{r}) \mathrm{p}$ ) and $\mathrm{ABp}$ (mainly in anterior granddaughters $A B p(l / r) a)$. This pattern is adapted by a second induction in the 12-cell stage, where a signal from MS to ABalp and ABara induces pharyngeal potential in those cells (Priess, 2005). We observed a similar fate pattern in the $8 \mathrm{AB}$ descendants of Rhabditophanessp., $H$. gingivalis and $P$. marinaalthough in varying percentages (Fig. 3). A third and fourth Notch interaction influence subsets of the $8 \mathrm{AB}$ precursors in the C. elegans embryo (Priess, 2005). At the 24-cell stage, an interaction occurs between ABalap and ABplaa, which induces the anterior daughter $A B p l a a a$ to develop differently from its bilateral homologue ABpraaa, forming left head epidermal precursors that are bilaterally symmetrical with ABarpap instead. Also in Rhabditophanessp., $P$. marina and $H$. gingivalis, ABalap contacts ABplaaa but not ABpraaa. Moreover, the ABplaaa descendants lie bilaterally symmetrical with the ABarpap descendants to form left and right head epidermal precursors. Finally the fourth induction occurs in the $C$. elegans embryo between MSap and ABplpa (Moskowitz and Rothman, 1996; Hutter and Schnabel, 1995), whereby the excretory cell is produced by a descendant of ABplpa (ABplpappaap). Again, both the initial positioning of cells and the resulting fate in the four species compared here are identical. These results might suggest that the inductions in those nematode species may be similar if not the same, strengthening the hypothesis that Notch inductions may be an underlying mechanism common to nematodes of clade IV and V. However, the presence of these inductions in the other species needs to be tested by laser ablation experiments.

\section{Secondary bilateral symmetries in $A B$ are identical in clade IV and V}

It is clear from the fate distribution in $A B$ in the four species compared here, that in some equivalent left-right sublineages of the $\mathrm{ABa}$ lineage the bilateral symmetry is lost, while the symmetry is largely retained in the $A B p$ lineage. These equivalent sublineages give rise to non-equivalent cell types (for example, compare fate distribution in ABala and ABara in Fig. 3). This bilateral asymmetry in the $A B$ lineage originates at the left-right division of the $2 A B$ cell stage in the 6-cell stage embryo. The left daughters of the $2 A B$ cells, $\mathrm{ABal}$ and $\mathrm{ABpl}$, are skewed in the anterior direction, and their progeny lie in more anterior positions than their lineal equivalents $A B$ ar and ABpr. Still in all species studied, a bilaterally symmetrical nematode arises from these asymmetrical lineages. The bilateral symmetry in the embryo is restored by asymmetric lineage pairs. We scored the position of the descendants of these sublineage pairs in $P$. marina, Rhabditophanes sp. and $H$. gingivalis. Sixteen of the secondary symmetries found in $C$. elegans are also scored in the Rhabditophanes sp. embryo and 14 in $H$. gingivalis.

In $C$. elegans, this bilaterally asymmetric lineage is the result of a signaling pathway, which superimposes the bilateral symmetry of the nematode body plan on a 6-cell stage embryo that is asymmetrically arranged after the skewed left-right division of $\mathrm{ABa}$ and ABp (Sulston et al., 1983; Wood, 1991). This single symmetry breakage event in the early embryo was found in each species we studied in clade IV and V. Although the underlying cell specification mechanisms remain to be ascertained, the result is

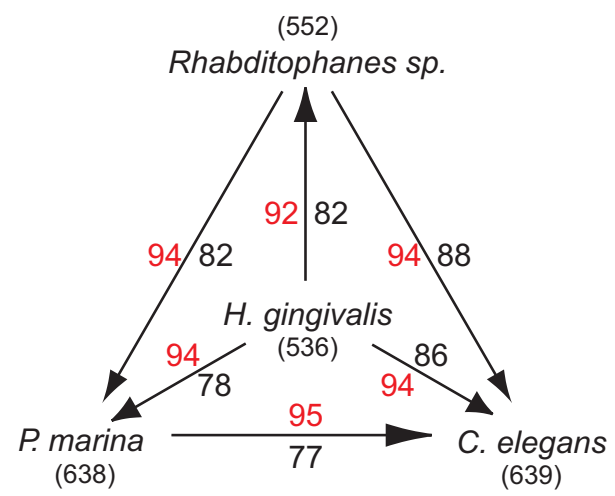

Fig. 2. Lineage and fate similarities between the embryonic cell lineages of $\boldsymbol{C}$. elegans, $\boldsymbol{H}$. gingivalis, $\boldsymbol{P}$. marina and $\boldsymbol{R h a b d i t o p h a n e s}$ $\boldsymbol{s p}$. Lineage similarity, indicated in red, is expressed as the number of terminal cells in the first species that have an identical lineage history as in the second species. Fate similarity, indicated in black, is expressed as the percentage of equivalent cells (with identical lineage history) of the first species that has the same cell fate as in the second species. The direction of the arrow indicates how the comparison was performed. The number of resolved terminal cells in the cell lineage of each species is indicated between brackets.

the same: an asymmetric cell lineage that compensates for the asymmetry in the early embryo. We hypothesize that this symmetry-breaking event in the ancestor of the nematodes of clade IV$V$ is a major developmental constraint that shapes the subsequent asymmetric polyclonal cell lineage in those nematodes. The studies on the early development of nematodes from clade I-III indicate that early embryos in these more basal clades are symmetric (Malakhov, 1994; Lahl et al., 2003). It remains to be seen however if these symmetric cells in early embryos give rise to a symmetric cell lineage.

\section{Materials and Methods}

\section{Cultures}

The soil nematode Rhabditophanes sp. KR3021 is cultured on 1\% agar plates with Escherichia coli OP50 as food source. Culture and handling is as described by Brenner (1974).

\section{D microscopy and cell lineage analysis}

Early stage embryos are obtained by cutting gravid females in distilled water. One-cell embryos are selected under a dissecting microscope, mounted on a slide with a $5 \%$ agar pad, covered with a coverslip and sealed with Vaseline (Sulston and Horvitz, 1977).

The cell lineage of the embryo is established using 4D microscopy described in detail by (Schnabel et al., 1997; Houthoofd et al., 2003). The recordings are analyzed with the software program Simi Biocell (Simi Gmbh, D-85705 Unterschleissheim, Germany). The embryonic cell lineage is established by identifying all cells and cell divisions in space and time. By establishing the positions of all the nuclei of the cells, 3Dreconstructions of the embryo are made and cell migrations can be followed. At muscle contraction, all tissues are clearly distinguishable, so the cell fate of each terminal cell is determined. It is not always possible to accurately identify the cell type of a given tissue. When discussing the nervous system, no distinction can always be made between neurons, sockets or sheaths; similarly, for cell types of the pharynx.

The lineages presented here are based on three recordings. A 


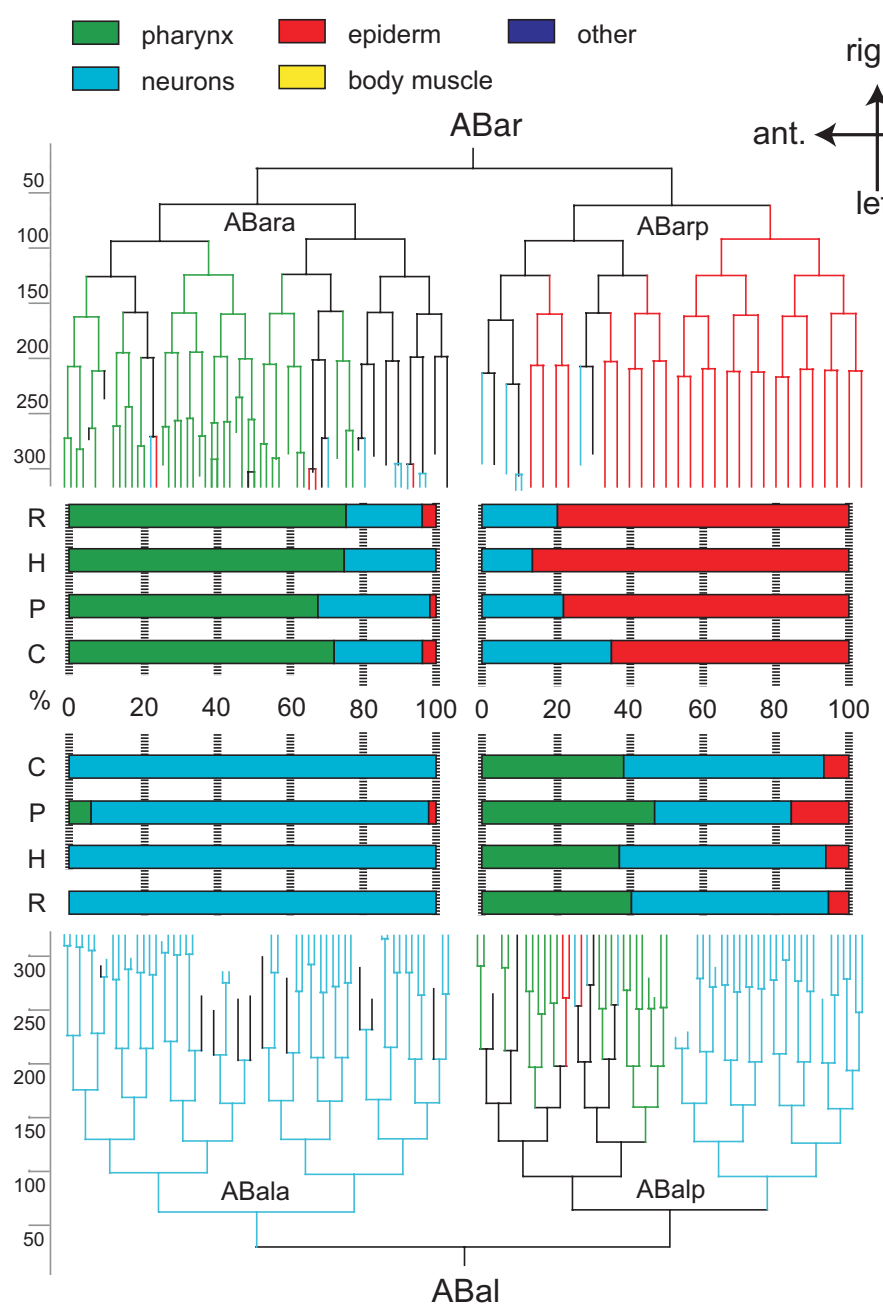

right
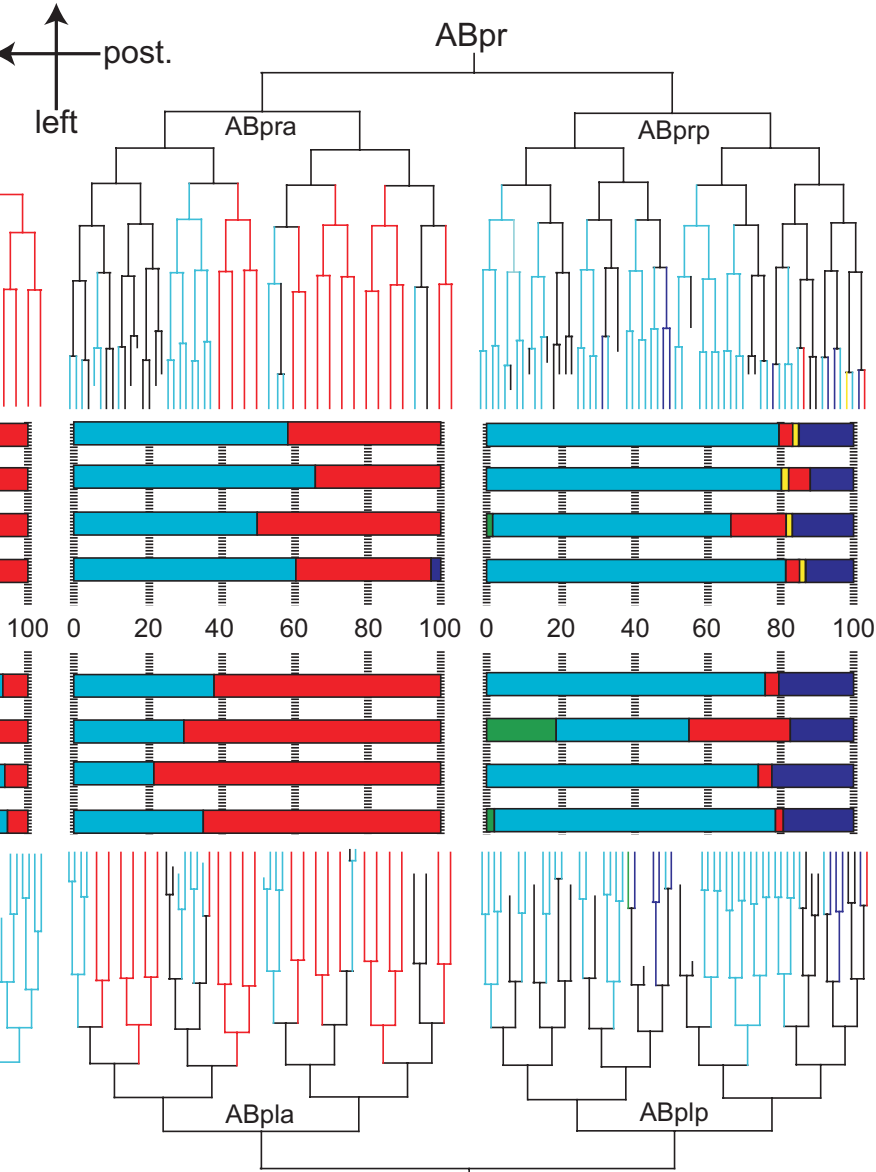

ABal

$\mathrm{ABpl}$

Fig. 3. AB cell lineage of Rhabditophanes sp.: comparison with $\boldsymbol{C}$. elegans, $\boldsymbol{H}$. gingivalis and $\boldsymbol{P}$. marina of the fate distribution in the $8 \mathrm{AB}$ granddaughters. The lineages of the 8 granddaughters are oriented according to their spatial position in the embryo (dorsal view, anterior to the left). Terminal cells and precursor cells that give rise to one tissue type are colored according to cell fate: pharynx: green; neuron: blue; epidermis: red; body muscle: yellow; other: dark blue. Cell deaths or cells with unresolved cell fate are colored black. The fate distribution of each AB granddaughter is compared between Rhabditophanes sp. (R), H. gingivalis (H), P. marina (P) and C. elegans $(C)$ in percentage of cells of each cell fate to the total number of terminal cells in each granddaughter. Timeline is given to the left of the figure in minutes after first division.

consensus lineage is formed, by which uncertainties in two complete recordings were resolved by comparison with the third recording. In Rhabditophanessp. the mitoses of some cells could not be resolved in all three recordings and are marked as unresolved mitoses. Also the terminal position and/or fate of some terminal cells could not be resolved and are marked as unresolved cells.

The cells are named according to (Sulston and Horvitz, 1977, Deppe et al., 1978; Sulston et al., 1983). Here we repeat shortly the nomenclature for better readability of the study. Founder cells formed in the first division rounds are given arbitrary names in capital letters (Deppe et al., 1981). When a founder cell divides, each daughter is named by adding to the name of the mother cell a single low-case letter representing its position immediately after division relative to its sister cell. For divisions in anterior-posterior direction the anterior and posterior daughter are indicated respectively with an 'a' and 'p', dorso-ventral divisions are indicated with ' $d$ ' and ' $v$ ', left-right divisions are indicated with 'l' and ' $r$ '. For example when founder cell $A B$ divides in anterior-posterior direction, the daughters are named $A B a$ and $A B p$ and when $A B p$ divides in left-right direction its daughters are named $A B p l$ and $A B p r$. A pair of cells may be designated by the use of internal parentheses, e.g., $A B a(1 / r)$ aa means $A B a l a a$ and $A B a r a a$. In the cell lineage tree the ' $a$ ', ' $d$ ' and ' $l$ ' daughters are represented by the left branches, and the ' $p$ ', ' $v$ ' and ' $r$ ' daughters by right branches.

\section{Acknowledgments}

We thank P. De Ley for the strain. This work was supported by doctoral grants to WH and MW by the Institute for the Promotion of Innovation through Science and Technology in Flanders (IWT-Vlaanderen) and funding from FWO and BOF to $G B$.

\section{References}

BLAXTER, M.L., DE LEY, P., GAREY, J.R., LIU L.X., SCHELDEMAN, P. VIERSTRAETE, A., VANFLETEREN, J.R., MACKEY, L.Y., DORRIS, M., FRISSE, L.M., VIDA, J.T. and THOMAS, W.K. (1998). A molecular evolutionary framework for the phylum Nematoda. Nature 392: 71-75.

BRENNER, S. (1974). The genetics of Caenorhabditis elegans. Genetics77: 71-94. 
DEPPE, U., SCHIERENBERG, E., COLE, T., KRIEG, C., SCHMITT, D., YODER, B. and VON EHRENSTEIN, G. (1978). Cell lineages of the embryo of the nematode Caenorhabditis elegans. Proc. Natl. Acad. Sci. U.S.A. 75: 376-380.

HOUTHOOFD, W., JACOBSEN, K., MERTENS, C., VANGESTEL, S., COOMANS, A. and BORGONIE, G. (2003). Embryonic cell lineage of the marine nematode Pellioditis marina. Dev. Biol. 258: 57-69.

HOUTHOOFD, W., WILLEMS, M., VANGESTEL, S., MERTENS, C., BERT, W. and BORGONIE G. (2006). Different roads to form the same gut in nematodes. Evol. Dev. 8: 4 362-369.

HOUTHOOFD, W., and BORGONIE, G (2007). The embryonic cell lineage of the nematode Halicephalobus gingivalis (Nematoda: Cephalobina: Panagrolaimoidea). Nematology 9: 573-584.

HUTTER, H. and SCHNABEL, R. (1995). Establishment of left-right asymmetry in the Caenorhabditis elegans embryo: a multistep process involving a series of inductive events. Development 121: 3417-3424.

LAHL, V., HALAMA, C. and SCHIERENBERG, E. (2003). Comparative and experimental embryogenesis of Plectidae (Nematoda). Dev. Genes Evol. 213: 18-27.

MALAKHOV, V.V. (1994). Nematodes, Structure, Development, Classification and Phylogeny. Smithsonian Institution Press, Washington DC.

MOSKOWITZ, I.P. and ROTHMAN, J.H. (1996). lin-12 and glp-1 are required zygotically for early embryonic cellular interactions and are regulated by maternal GLP-1 signalling in Caenorhabditis elegans. Development 122: 41054117.

PRIESS, J. (2005). Notch signaling in the C. elegans embryo. In: The C. elegans
Research Community (Ed.) WormBook, 2005, http://www.wormbook.org.

RIDDLE, D.L., BLUMENTHAL, T., MEYER and B.J., PRIESS, J.R. (Eds.) (1997) C. elegans II. Cold Spring Harbor Laboratory Press, Cold Spring Harbor New York.

SCHIERENBERG, E. (2006). Embryological variation during nematode development. In: The C. elegans Research Community (Ed.) WormBook, 2006, http:// www.wormbook.org

SCHNABEL, R., HUTTER, H., MOERMAN, D. and SCHNABEL, H. (1997). Assessing normal embryogenesis in Caenorhabditis elegans using a 4D microscope: variability of development and regional specification. Dev. Biol. 184: 234-265

SOMMER, R.J. (2005). Evolution of development in nematodes related to C. elegans, In: The C. elegans Research Community (Ed.) WormBook, 2005, http:/ /www.wormbook.org.

SULSTON, J.E. and HORVITZ, H.R. (1977). Post-embryonic cell lineages of the nematode Caenorhabditis elegans. Dev. Biol. 82: 41-55.

SULSTON, J.E., SCHIERENBERG, E., WHITE, J.G. and THOMAS, J.N. (1983). The embryonic cell lineage of the nematode Caenorhabditis elegans. Dev. Biol. 100: $64-119$

THE C. ELEGANS RESEARCH COMMUNITY (Eds.). WormBook, doi/10.1895/ wormbook.1.7.1, http://www.wormbook.org.

WOOD, W.B. (Ed.) (1988). The nematode Caenorhabditis elegans. Cold Spring Harbor Laboratory Press, Cold Spring Harbor New York.

WOOD, W.B. (1991). Evidence for reversal of handedness in C. elegans embryos for early interactions determining cell fates. Nature 349: 536-538.

\section{Further Related Reading, published previously in the Int. J. Dev. Biol.}

See our recent Special Issue Fertilization, in honor of David L. Garbers and edited by Paul M. Wassarman and Victor D. Vacquier at: http://www.ijdb.ehu.es/web/contents.php?vol=52\&issue=5-6

See our recent Special Issue Ear Development edited by Fernando Giraldez and Bernd Fritzsch at: http://www.ijdb.ehu.es/web/contents.php?vol=51\&issue=6-7

Egg development in parthenogenetic nematodes: variations in meiosis and axis formation Vera Lahl, Bernd Sadler and Einhard Schierenberg

Int. J. Dev. Biol. (2006) 50: 393-397

2006 ISI **Impact Factor $=3.577^{* *}$

From embryonic induction to cell lineages: revisiting old problems for modern study

Tokindo S. Okada

Int. J. Dev. Biol. (2004) 48: 739-742

Differences in maternal supply and early development of closely related nematode species

Magdalena Laugsch and Einhard Schierenberg

Int. J. Dev. Biol. (2004) 48: 655-662

The use of fluorescent marker dyes for studying intercellular communication in nematode embryos.

$\mathrm{O}$ Bossinger and $\mathrm{E}$ Schierenberg

Int. J. Dev. Biol. (1996) 40: 431-439

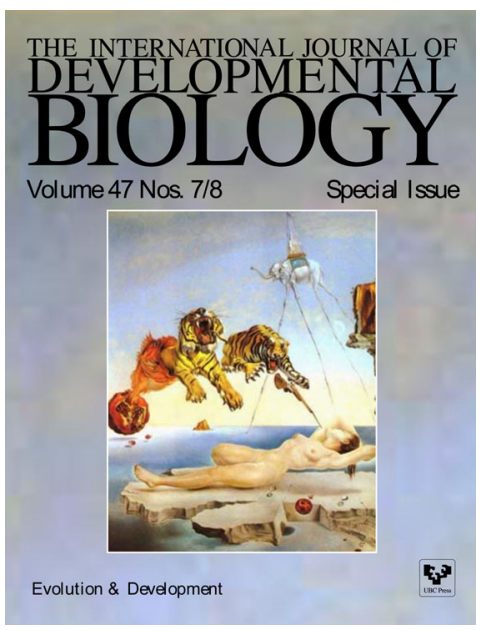

